\title{
Antioxidant Capacity of Free Volatile Compounds from Olea europaea L. cv. Oblica Leaves Depending on the Vegetation Stage
}

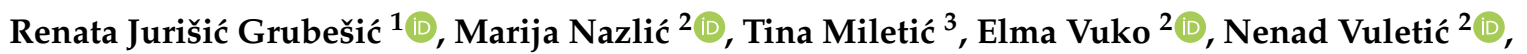 \\ Ivica Ljubenkov ${ }^{2}$ and Valerija Dunkić ${ }^{2, *}$ (D) \\ 1 Faculty of Medicine, University of Rijeka, Braće Branchetta 20, HR-51000 Rijeka, Croatia; \\ renatajg@medri.uniri.hr \\ 2 Faculty of Science, University of Split, Ruđera Boškovića 33, HR-21000 Split, Croatia; \\ mnazlic@pmfst.hr (M.N.); elma@pmfst.hr (E.V.); nenov@pmfst.hr (N.V.); iljubenk@pmfst.hr (I.L.) \\ 3 Pharmacy "Vaše Zdravlje”, Put Kotlara 50, Zadar, HR-23000 Zadar, Croatia; tina.miletic@vasezdravlje.hr \\ * Correspondence: dunkic@pmfst.hr; Tel.: +385-21-619-296
}

Citation: Jurišić Grubešić, R.; Nazlić, M.; Miletić, T.; Vuko, E.; Vuletić, N.; Ljubenkov, I.; Dunkić, V. Antioxidant Capacity of Free Volatile Compounds from Olea europaea L. cv. Oblica Leaves Depending on the Vegetation Stage. Antioxidants 2021, 10, 1832. https://doi.org/10.3390/ antiox10111832

\section{Academic Editors:}

Juan Fernández-Bolaños and

Alejandra Bermudez-Oria

Received: 29 October 2021

Accepted: 15 November 2021

Published: 18 November 2021

Publisher's Note: MDPI stays neutral with regard to jurisdictional claims in published maps and institutional affiliations.

Copyright: (c) 2021 by the authors. Licensee MDPI, Basel, Switzerland. This article is an open access article distributed under the terms and conditions of the Creative Commons Attribution (CC BY) license (https:/ / creativecommons.org/licenses/by/ $4.0 /)$.

\begin{abstract}
Previous research on specialized metabolites of olive leaves has focused on the phenolic components and their biological role. The research in this article focuses on the metabolites that form free volatile compounds (FVCs). The composition of FVCs is divided into compounds isolated in the oil phase (essential oils; EO) and in the aqueous phase (hydrosols; Hy) from leaves of Olea europaea L. cultivar Oblica. Plant material was collected from the same olive tree over a six-month period, from December to May, and analyzed by gas chromatography-mass spectrometry (GC-MS). The compounds $\beta$-caryophyllene, $\alpha$-humulene, allo-aromadendrene, docosane, hexadecanoic acid and oleic acid were identified in all EO study periods. In the Hy in all studied periods, the major compounds are $\alpha$-pinene, $\beta$-ionone, myristicin, docosane, 1 -hexanol, oleic acid and (E)- $\beta$-damascenone. The differences in the qualitative composition of FVC are directly related to the phenological development of the leaves. Antioxidant capacity of the EOs and hydrosols was measured with two methods, ORAC and DPPH. Hydrosol extracts showed higher capacity than the EOs in all methods.
\end{abstract}

Keywords: antioxidant capacity; docosane; (E)- $\beta$-damascenone; essential oil; gas chromatographymass spectrometry (GC-MS); hydrosol; myristicin; olea leaves; oleic acid

\section{Introduction}

Olea europaea L. (Oleaceae)-the olive-is cultivated in various parts of the world, with the Mediterranean region still being the largest growing region due to its climate of warm, dry summers and cold, rainy winters [1]. This plant is so popular because the Mediterranean diet is considered one of the healthiest diets in the world and olive oil is one of the most important dietaries of this diet [2].

Of the six subspecies of olive, only three are naturally distributed in the Mediterranean: subsp. europaea, subsp. guanchica, and subsp. cerasiformis. Olea europaea subsp. europaea is a subspecies considered drought resistant because it grows in an areas where it is frequently exposed to stress (e.g., lack of water), which is characteristic of the Mediterranean region [3]. It is divided into a wild form O. europaea subsp. europaea var. sylvestris and a cultivated form O. europaea subsp. europaea var. europaea [4]. The area under olive cultivation in Croatia is very large and the most important variety is "Oblica", which is the subject of the present study [5,6].

Olive leaves are one of the by-products of olive cultivation and are available throughout the year. Since the leaf is a plant organ where most of the primary and specialized metabolism takes place, it is clear that it is an important source of bioactive components responsible for numerous pharmacological effects [7]. 
Although the fruit has been the most commonly used part of the olive since ancient times, the olive leaf has also been traditionally used for various purposes: orally to treat various intestinal disorders; the leaf was chewed to treat diseases of the oral cavity; in the form of a decoction, the leaf was used to treat diarrhea and urinary tract infections; a hot aqueous extract of fresh leaves was used orally to treat hypertension and stimulate urination, while a hot aqueous extract of dried leaves was used to treat asthma. Olive leaves have also been found to have a beneficial effect on the circulatory system, reducing muscle spasms in the intestines and relieving cardiac arrhythmias [8-11].

The bioactivity of olive leaves has traditionally been associated with their phenolic derivative content. Olive leaves contain five groups of phenolic compounds: oleuropeosides (oleuropein and verbascoside), flavones (luteolin-7-glucoside, apig-enin-7glucoside, diosmetin-7-glucoside, luteolin and diosmetin), flavonols (rutin), flavan-3-ols (catechin) and substituted phenols (tyrosol, hydroxytyrosol, vanillin, vanillic acid and caffeic acid) [12,13]. Many researchers agree that oleuropein is the compound in olive leaf that is most responsible for its beneficial effects on health, as its hydrolysis products also exhibit significant pharmacological effects [14-17]. Oleuropein has several proven biological activities such as antioxidant, anti-inflammatory, anticancer, antiatherogenic, antimicrobial, antiviral, cardioprotective, anti-ischemic, neuroprotective and hypolipidemic activity [18]. It has a beneficial effect on age-related diseases, such as dementia. Other biological activities include lowering blood sugar levels, liver protection, stomach protection, weight loss and osteoporosis prevention [19]. It is also used in cosmetics as it protects against UVB rays, slows the aging process, and promotes wound healing and re-epithelialization $[20,21]$. Many phenolic compounds isolated from olive leaves can exert a pronounced antioxidant activity, which in turn can accelerate the healing process of ulcers [22]. Generally, the olive leaf has the highest antioxidant activity of all parts of the olive tree [11,23]. Olive leaf contains a greater amount and variety of polyphenols than extra virgin olive oil. Moreover, there are important structural differences between polyphenols from olive leaves compared to those from fruits that could have the more significant beneficial effect of olive leaf extract on human health [16].

These polyphenols components belong to the specialized metabolites as well as the terpenoid components, also described in olive leaves, including monoterpenes, sesquiterpenes, diterpenes and triterpenes [16,24]. These free volatile compounds (FVCs) have been best studied in olive fruit and are dominated by C5 and C6 compounds [25]. GC and gas chromatography-mass spectrometry (GC-MS) analysis of essential oils (EO) in olive leaves from Tunisia resulted in the identification of 32 compounds, of which monoterpene hydrocarbons accounted for $55.16 \%$ of the total EO and $\alpha$-pinene $(52.70 \%)$ was the main compound. In this study DPPH radical-scavenging activity of EO compounds was investigated [26]. Also, $\alpha$-pinene was the main compound in olive leaves of Turkish variety [27]. Brazilian olive leaves contain a significant amount of polyunsaturated fatty acids [28]. Campeol et al. investigated the chemical composition of volatile fractions from leaves of three Olea europaea L. cultivars Leccino, Frantoio and Cipressino from Italy harvested in two different seasons by GC and GC-MS. The results showed a high content of aliphatic aldehydes and an increase in (E)-2-hexenal content from July to November [29]. Extracts obtained from wild olive leaves (O. europaea ssp. sylvestris) also showed important biological activity [30].

In previous study by Popović et al., EOs from leaves of O. europaea subsp. europaea of Croatian cultivars: Oblica, Lastovka, Leccino and Frantoio were investigated in the period of August, September and October. The results showed that Oblica cultivar EO was abundant in aldehydes, ketones and sesquiterpenes [6]. Despite the numerous biological effects of polyphenols contained in olive leaves, the hydrosols obtained from olive leaves have never been phytochemically analyzed, and we hypothesize that these harmless water extracts may be a readily available source of biologically active substances with antioxidant capacity. In addition, phytochemical analysis of essential oils and hydrosols over a continuous period of six months, as performed in this study, will provide information 
on the composition of olive volatiles in the lipophilic and aqueous fractions over a longer period of the year, as well as on the antioxidant activity of these extracts in different vegetative phases, from winter period to flowering phase. Our team decided to study FVCs during this period because this is the time of pruning of olive trees. The leaves obtained and their extracts could be a source of biologically active substances that could be used for the protection of food, natural cosmetic products and natural-based pharmaceuticals. Previous research on olives in relation to months has focused on temperature changes, which are important for the onset of flowering [28]. Our research focuses on the antioxidant capacity of free volatile compounds in the essential oils and hydrosols from the leaves of olive cv. Oblica. These studies have confirmed that, in addition to the already well-researched phenolic components, the free volatile compounds have a significant impact on the total antioxidant value of olive leaves.

\section{Materials and Methods}

\subsection{Plant Material and Isolation of Free Volatile Compounds}

Plant material for Olea europaea L cv. Oblica was collected from N 44 $18^{\prime} 40.70^{\prime \prime}$, E $15^{\circ} 16^{\prime} 27.23^{\prime \prime}$ location in Croatia (Ražanac, Zadar). Voucher specimens were deposited in the Laboratory of Botany herbarium (HPMF-HR), Faculty of Science, University of Split, Croatia. The first sample was collected on 12 December 2019; the second sample on 6 January 2020; the third sample on 3 February 2020; the fourth sample on 14 March 2020; the fifth sample on 14 April 2020 and the sixth sample on 14 May 2020. Samples were air dried in a single layer and protected from direct sunlight, for then days.

Dried olive leaves (100 g) for each month were hydrodistilled for $3 \mathrm{~h}$ in a Clevengertype apparatus (Šurlan, Medulin, Croatia). The extracts were collected in two phases in the inner tube of the Clevenger apparatus. The lipophilic fraction was extracted in pentane and diethyl ether (VWR, Radnor, PA, USA) and the hydrophilic volatile compounds were extracted in the water layer and stored in the refrigerator until analysis.

\subsection{Extraction of Volatiles from Hydrosols}

Volatiles dissolved in water fraction have been extracted with pentane/diethyl ether mixture to determine antioxidant capacity of hydrosols and compare it with EO antioxidant capacity. Each hydrosol $(5 \mathrm{~mL})$ was extracted with the mixture of $3 \mathrm{~mL}$ of pentane and $3 \mathrm{~mL}$ of diethyl ether in a separation funnel. The nonpolar layer was separated and dried over the anhydrous sodium sulphate. The solvent from the nonpolar layer was evaporated to calculate the exact concentration of hydrosol. The volatile compounds that remained were weighed and the concentration for each hydrosol sample was calculated and expressed in $\mathrm{mg} / \mathrm{mL}$ of hydrosol.

\subsection{Gas Chromatography, Gas Chromatography-Mass Spectrometry and Columns Conditions}

Both phases, lipophilic and hydrophilic were analyzed by GC and GC-MS. GC was performed using model 3900; Varian Inc., Lake Forest, CA, USA equipped with a flame ionization detector (FID), a MS model 2100T; Varian Inc., Palo Alto, CA, USA. The chromatographic conditions were: FID detector temperature $300^{\circ} \mathrm{C}$, injector temperature $250{ }^{\circ} \mathrm{C}$, the carrier gas was helium at $1 \mathrm{~mL} \mathrm{~min}^{-1}$. The $\mathrm{MS}$ conditions were: ion source temperature $200{ }^{\circ} \mathrm{C}$, ionization voltage $70 \mathrm{eV}$, mass scan range $40-350$ mass units [31,32].

Samples were analyzed on two columns: non-polar capillary column VF-5ms (30 $\mathrm{m} \times 0.25 \mathrm{~mm}$ i.d., coating thickness $0.25 \mu \mathrm{m}$, Palo Alto, CA, USA) and a polar CP Wax $52 \mathrm{CB}$ (30 $\mathrm{m} \times 0.25 \mathrm{~mm}$ i.d., coating thickness $0.25 \mu \mathrm{m}$; Palo Alto, CA, USA) was equipped. The conditions for the columns were: VF-5ms (temperature $60{ }^{\circ} \mathrm{C}$ isothermal for $3 \mathrm{~min}$, then increased to $246^{\circ} \mathrm{C}$ at a rate of $3{ }^{\circ} \mathrm{C} \mathrm{min}-1$, and held isothermal for $25 \mathrm{~min}$ ) and for the CP Wax 52 column (temperature $70^{\circ} \mathrm{C}$ isothermal for $5 \mathrm{~min}$, then increased to $240{ }^{\circ} \mathrm{C}$ at a rate of $3{ }^{\circ} \mathrm{C} \mathrm{min}^{-1}$, and held isothermal for $25 \mathrm{~min}$ ). 


\subsection{Analyses of Free Volatile Compounds}

The injected volume for lipophilic fractions were $2 \mu \mathrm{L}$ and the split ratio was 1:20. For the hydrophilic fraction, injection was performed with a headspace injection needle and there was no split ratio (splitless mode). The $2 \mathrm{~g}$ of hydrosol was added to the glass bottle and sealed with a metal cap with septum. The headspace needle was injected into the glass bottle sealed with a metal cap with septum. The glass bottle was first placed in $40{ }^{\circ} \mathrm{C}$ water with the hydrosol sample and left there for $20 \mathrm{~min}$ without the needle to allow the volatile compounds to evaporate from the water. The needle was then injected and left there for $20 \mathrm{~min}$ to allow the volatile compounds to adsorb onto the resin needle. The injection needle was then inserted into a GC inlet and left there for $20 \mathrm{~min}$ [33]. Analyses was started after the $10 \mathrm{~min}$ of resorption in the liner and the needle was left in the liner for $10 \mathrm{~min}$ more during the analyses to ensure that all volatile compounds were reabsorbed from the resin into the injection liner.

The individual peaks for all samples were identified by comparing their retention indices of n-alkanes with those of authentic samples and literature [31]. The results for all samples were measured in three independent analyzes and expressed as a percentage (\%, relative peak area) of each compound (Tables 2 and 3$)$.

\subsection{Antioxidant Capacity of Essential Oils and Hydrosols}

\subsubsection{ORAC}

The assay was performed in a Perkin-Elmer LS55 spectrofluorimeter (Perkin-Elmer, Leatherhead, UK), using 96-well white polystyrene microtiter plates (Porvair Sciences, Leatherhead, UK) following a method described by Fredotović et al. [34], with some adjustments based on different extracts. Hydrophilic assay was performed for hydrosols and lipophilic assay for EOs. Adjustments were made for the EO antioxidant assay. EOs were dissolved in acetone (10 $\mathrm{mg}$ in $1 \mathrm{~mL}$ acetone). The $\mathrm{EO}$ acetone dilutions were further dissolved $40 \times$ and $80 \times$ in the phosphate buffer prior to the experiments. Hydrosols were diluted $2 \times$ and $10 \times$ in the phosphate buffer prior to the experiments. All measurements were performed in triplicate according to the method described in Nazlić et al. [33].

\subsection{2. $\mathrm{DPPH}$}

The antioxidant capacity of the extracts was determined using the DPPH method already described by Mensor et al. and Payet et al. $[35,36]$ and adapted to tested plant extracts. Plant extracts as described in the ORAC method were used (acetone-dissolved essential oils and absolute hydrosols) for the assay. An amount of $100 \mu \mathrm{L}$ of methanol (Kemika, Zagreb, Croatia) and $200 \mu \mathrm{L}$ of sample was pipetted into each well. Serial dilutions of samples were prepared by pipetting $100 \mu \mathrm{L}$ from the first row with a multichannel pipette into the wells in the second row and so on to the last row, where $100 \mu \mathrm{L}$ of the solution was ejected after mixing. In the first column, in 96-well plates, a blank sample was always added. For EOs, the acetone and methanolic solution were used as blank and for hydrosols, water and methanolic solution were used as blank. The calculation and presentation of the results were performed according to the method described in the previous research by Nazlić et al. [33].

\subsection{Statistical Analyses}

Statistical analysis was performed in GraphPad Prism Version 9 (GraphPad Software, San Diego, CA, USA). All data are expressed as mean \pm SD $(n \geq 3)$. The statistical significance for antioxidant activity was assessed by 2-way ANOVA followed by Šídák's multiple comparisons test, $p<0.05$. These statistical tests were performed separately for lipophilic (essential oils) and hydrophilic fractions (hydrosols). 


\section{Results and Discussion}

\subsection{Pretreatment and Isolation of Free Volatile Compounds from Olive Leaves}

During a period of six months the leaves of Olea europaea L. cultivar Oblica were collected. Oblica is the most widespread native variety in the Mediterranean part of Croatia. It tolerates stressful conditions well and develops a medium-sized, lush tree with a round crown and numerous grey-olive leaves with non-glandular trichomes [5]. Olive trichomes are transcriptionally active and represent a tissue involved in developmental processes and specialized metabolism [37]. Leaves for this study were collected from December to May (Table 1), the period after olive harvest, from winter dormancy to flowering. The differences in the composition of free volatiles under different climatic conditions were studied, while the geographical location and soil were the same, since leaves were collected from the same olive tree. The collected olive leaves were air dried. Several studies have reported different types of pretreatment of collected olive leaves before extraction. Pretreatment is important for the isolation of the target substances, therefore olive leaves are prepared under different conditions (air, water and temperature) for extraction [9].

Table 1. Yield of obtained volatile compounds from essential oils (EOs) and hydrosols (Hy) of Olea europaea cv. Oblica.

\begin{tabular}{ccccc}
\hline Month & $\begin{array}{c}\text { Mass of EO } \\
(\mathbf{m g})\end{array}$ & $\begin{array}{c}\text { Yield of EO } \\
\mathbf{( \% )}\end{array}$ & $\begin{array}{c}\text { Mass of Volatiles } \\
\text { from Hy } \mathbf{( m g )}\end{array}$ & $\begin{array}{c}\text { Yield of Volatiles } \\
\text { from Hy (\%) }\end{array}$ \\
\hline December & 100 & 0.1 & 204 & 0.20 \\
January & 100 & 0.1 & 134 & 0.13 \\
February & 100 & 0.1 & 162 & 0.16 \\
March & 40 & 0.04 & 221 & 0.22 \\
April & 200 & 0.2 & 191 & 0.19 \\
May & 80 & 0.08 & 225 & 0.23 \\
\hline
\end{tabular}

Various extracts have been prepared from olive leaves: ethanol/water extracts obtained with microwaves and different combinations of extractions with ethanol, butanol/ethyl acetate fractions, hexane, chloroform/water fractions and water/ethanol/citric acid [38]. In this study, two phases of extracts were collected in a central measuring tube of the Clevenger apparatus. Pentane and diethyl ether were used as solvents of EOs. FVCs were isolated in the lower aqueous layer and in the upper pentane/diethyl ether layer. The common name for the volatiles soluble in pentane is essential oils and those soluble in water are hydrosols. Table 1 shows the masses of the isolated volatile compounds of the EOs and hydrosols, and the yields were calculated based on the dry plant material used for the extractions. It can be seen that a greater amount of volatile compounds is isolated in the hydrosols which could be the reason for the higher antioxidant capacity of these extracts compared to the EOs.

\subsection{GC and GC-MS Identification of Free Volatile Compounds from Olive Leaves}

The volatile compounds in the essential oil and hydrosols of O. europaea cv. Oblica were analyzed by GC and GC-MS and are listed in Tables 2 and 3 in the order of elution from the non-polar column. 
Table 2. Chemical composition of the essential oil of Olea europaea L. cv. Oblica from six months.

\begin{tabular}{|c|c|c|c|c|c|c|c|c|}
\hline \multicolumn{9}{|c|}{ Month of Collection/ Yield in \%/ Yield in \% \pm SD } \\
\hline Component & $\mathbf{R I}^{1}$ & $\mathrm{RI}^{2}$ & $\begin{array}{l}\text { December } \\
(0.1 \%)\end{array}$ & $\begin{array}{c}\text { January } \\
(0.1 \%)\end{array}$ & $\begin{array}{c}\text { February } \\
(0.1 \%)\end{array}$ & $\begin{array}{l}\text { March } \\
(0.04 \%)\end{array}$ & $\begin{array}{l}\text { April } \\
(0.2 \%)\end{array}$ & $\begin{array}{c}\text { May } \\
(0.08 \%)\end{array}$ \\
\hline Monoterpene hydrocarbons & & & 1.9 & 0.38 & 0.28 & - & - & - \\
\hline$\alpha$-Thujene & 924 & 1012 & $0.62 \pm 0.01$ & - & - & - & - & - \\
\hline$\alpha$-Pinene * & 935 & 1017 & $0.32 \pm 0.01$ & $0.38 \pm 0.01$ & - & - & - & - \\
\hline Myrcene & 988 & 1160 & $0.75 \pm 0.01$ & - & - & - & - & - \\
\hline$\beta$-Thujone & 1121 & 1451 & $0.21 \pm 0.05$ & - & $0.28 \pm 0.01$ & - & - & - \\
\hline Oxygenated monoterpenes & & & 1.41 & - & 9.9 & - & - & - \\
\hline Linalool * & 1099 & 1548 & $0.88 \pm 0.01$ & - & $9.35 \pm 0.01$ & - & - & - \\
\hline Borneol * & 1176 & 1699 & $0.21 \pm 0.04$ & - & $0.17 \pm 0.03$ & - & - & - \\
\hline Terpinen-4-ol & 1184 & 1601 & $0.32 \pm 0.01$ & - & $0.38 \pm 0.01$ & - & - & - \\
\hline $\begin{array}{l}\text { Sesquiterpene } \\
\text { hydrocarbons }\end{array}$ & & & 10.48 & 16.58 & 24.32 & 32.37 & 30.86 & 40.57 \\
\hline$\alpha$-Cubebene & 1345 & 1458 & - & - & $10.54 \pm 0.01$ & - & - & - \\
\hline$\alpha$-Copaene & 1374 & 1484 & - & $3.29 \pm 0.03$ & - & - & - & $7.79 \pm 0.01$ \\
\hline$\beta$-Cubebene & 1387 & 1540 & - & - & $1.34 \pm 0.01$ & - & $2.64 \pm 0.01$ & $8.99 \pm 0.01$ \\
\hline$\beta$-Elemene & 1389 & 1593 & $1.64 \pm 0.01$ & $0.63 \pm 0.01$ & - & - & - & $0.66 \pm 0.07$ \\
\hline$\beta$-Caryophyllene * & 1424 & 1585 & $2.82 \pm 0.01$ & $2.87 \pm 0.02$ & $1.86 \pm 0.01$ & $10.45 \pm 0.01$ & $0.39 \pm 0.06$ & $1.26 \pm 0.01$ \\
\hline (Z)- $\beta$-Farnesene & 1454 & 1639 & $0.24 \pm 0.1$ & $0.29 \pm 0.01$ & - & - & - & - \\
\hline$\alpha$-Humulene & 1456 & 1654 & $0.75 \pm 0.01$ & $0.78 \pm 0.01$ & $0.78 \pm 0.01$ & $0.72 \pm 0.01$ & $18.53 \pm 0.01$ & $14.75 \pm 0.01$ \\
\hline allo-Aromadendrene & 1465 & 1662 & $2.92 \pm 0.05$ & $2.98 \pm 0.02$ & $1.44 \pm 0.02$ & $20.94 \pm 0.01$ & $5.98 \pm 0.01$ & $4.74 \pm 0.01$ \\
\hline Germacrene D & 1481 & 1692 & $0.46 \pm 0.01$ & $0.99 \pm 0.03$ & $4.76 \pm 0.01$ & $0.26 \pm 0.02$ & $0.37 \pm 0.01$ & - \\
\hline$\beta$-Bisabolene & 1494 & 1729 & $0.63 \pm 0.01$ & $0.75 \pm 0.01$ & $0.64 \pm 0.07$ & - & - & - \\
\hline$\delta$-Cadinene & 1517 & 1745 & $0.75 \pm 0.01$ & $0.74 \pm 0.01$ & $0.71 \pm 0.01$ & - & - & - \\
\hline Oxygenated sesquiterpenes & & & 21.91 & 22.38 & 1.34 & - & 0.68 & 7.03 \\
\hline Spathulenol & 1577 & 2101 & $0.32 \pm 0.01$ & $0.35 \pm 0.05$ & $0.38 \pm 0.05$ & - & - & - \\
\hline Caryophyllene oxide * & 1581 & 1955 & $17.13 \pm 0.03$ & $21.27 \pm 0.01$ & $0.96 \pm 0.01$ & - & $0.68 \pm 0.01$ & - \\
\hline$\alpha$-Cadinol & 1655 & 2208 & $4.46 \pm 0.01$ & $0.76 \pm 0.03$ & - & - & - & $7.03 \pm 0.01$ \\
\hline Phenolic compounds & & & 33.02 & 27.85 & 4.18 & 2.03 & - & 2.95 \\
\hline Eugenol * & 1370 & 2175 & - & - & - & $0.91 \pm 0.1$ & & \\
\hline Myristicin & 1520 & 2260 & $33.02 \pm 0.01$ & $27.85 \pm 0.01$ & $4.18 \pm 0.01$ & $1.12 \pm 0.01$ & - & $2.95 \pm 0.01$ \\
\hline Hydrocarbons & & & 13.03 & 10.72 & 19.25 & 42.81 & 6.9 & 8.58 \\
\hline Heneicosane * & 2100 & 2100 & $0.23 \pm 0.01$ & $0.24 \pm 0.02$ & $0.26 \pm 0.01$ & - & $0.27 \pm 0.01$ & - \\
\hline Docosane * & 2200 & 2200 & $5.21 \pm 0.01$ & $4.54 \pm 0.03$ & $7.03 \pm 0.01$ & $40.12 \pm 0.01$ & $6.63 \pm 0.01$ & $3.46 \pm 0.01$ \\
\hline
\end{tabular}


Table 2. Cont

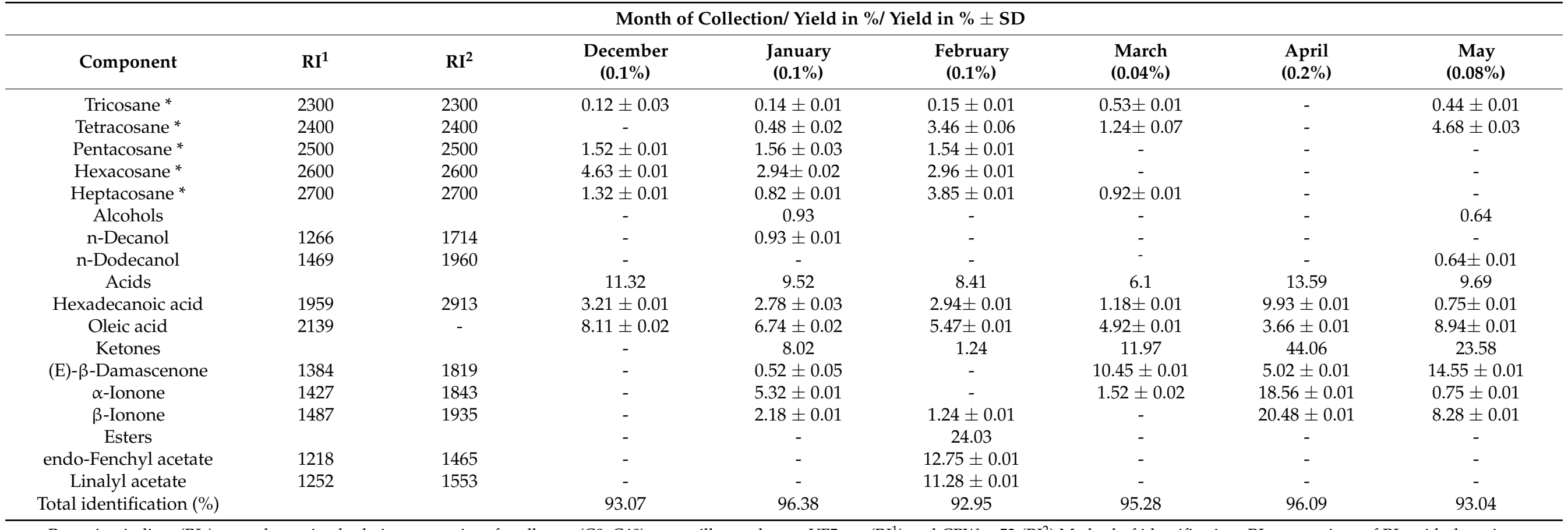

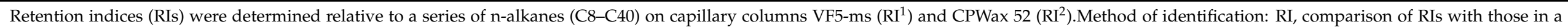

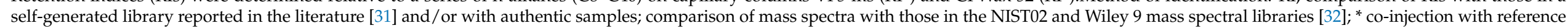
compounds; - , not identified; SD, standard deviation of triplicate analysis. 
Table 3. Chemical composition of the hydrosols of Olea europaea L. cv. Oblica from six months.

\begin{tabular}{|c|c|c|c|c|c|c|c|c|}
\hline \multicolumn{9}{|c|}{ Month of Collection/ Yield in $\% \pm$ SD } \\
\hline Component & $\mathbf{R I}^{\mathbf{1}}$ & $\mathbf{R I}^{2}$ & December & January & February & March & April & May \\
\hline Monoterpene hydrocarbons & & & 4.16 & 2.65 & 1.36 & 1.79 & 13.35 & 7.45 \\
\hline$\alpha$-Thujene & 924 & 1012 & - & - & - & - & $7.12 \pm 0.01$ & - \\
\hline$\alpha$-Pinene * & 935 & 1017 & $2.68 \pm 0.01$ & $2.65 \pm 0.01$ & $1.36 \pm 0.01$ & $1.79 \pm 0.01$ & $6.23 \pm 0.01$ & $7.45 \pm 0.01$ \\
\hline Myrcene & 988 & 1160 & $0.87 \pm 0.01$ & - & - & - & - & - \\
\hline$\beta$-Thujone & 1121 & 1451 & $0.61 \pm 0.01$ & - & - & - & - & - \\
\hline Oxygenated monoterpenes & & & 2.9 & - & 0.38 & - & 7.18 & 2.78 \\
\hline Linalool * & 1099 & 1548 & - & - & - & - & - & $0.97 \pm 0.01$ \\
\hline Borneol * & 1176 & 1699 & - & - & - & - & $1.27 \pm 0.01$ & - \\
\hline Terpinen-4-ol & 1184 & 1601 & - & - & - & - & $0.79 \pm 0.01$ & - \\
\hline$\alpha$-Terpineol & 1186 & 1690 & $2.18 \pm 0.01$ & - & - & - & $3.66 \pm 0.01$ & $0.67 \pm 0.07$ \\
\hline Myrtenol & 1197 & 1782 & $0.72 \pm 0.01$ & - & $0.38 \pm 0.01$ & - & $1.46 \pm 0.01$ & $1.14 \pm 0.01$ \\
\hline $\begin{array}{l}\text { Sesquiterpene } \\
\text { hydrocarbons }\end{array}$ & & & 3.98 & 7.26 & 1.31 & 41.97 & 3.31 & 9.71 \\
\hline$\alpha$-Copaene & 1374 & 1484 & - & - & - & - & - & $3.55 \pm 0.01$ \\
\hline$\beta$-Elemene & 1389 & 1593 & $1.16 \pm 0.05$ & - & - & $1.17 \pm 0.01$ & - & - \\
\hline$\beta$-Caryophyllene * & 1424 & 1585 & $2.82 \pm 0.01$ & $1.38 \pm 0.01$ & $1.31 \pm 0.01$ & $1.26 \pm 0.01$ & - & - \\
\hline$\beta$-Copaene & 1429 & 1576 & - & - & - & - & - & $0.86 \pm 0.01$ \\
\hline$\alpha$-Humulene & 1456 & 1654 & - & - & - & - & $2.07 \pm 0.01$ & $4.54 \pm 0.01$ \\
\hline allo-Aromadendrene & 1465 & 1662 & - & $0.38 \pm 0.03$ & - & - & - & - \\
\hline Germacrene D & 1481 & 1692 & - & $4.79 \pm 0.01$ & - & - & - & - \\
\hline$\beta$-Bisabolene & 1494 & 1729 & - & - & - & - & - & $0.76 \pm 0.01$ \\
\hline Bicyclogermacrene & 1500 & 1718 & - & - & - & $39.54 \pm 0.01$ & - & - \\
\hline$\delta$-Cadinene & 1517 & 1745 & - & $0.71 \pm 0.01$ & - & - & - & - \\
\hline Oxygenated sesquiterpenes & & & 2.71 & - & - & - & 2.39 & 1.92 \\
\hline Spathulenol & 1577 & 2101 & $0.47 \pm 0.01$ & - & - & - & $0.42 \pm 0.01$ & - \\
\hline Caryophyllene oxide * & 1581 & 1955 & $0.96 \pm 0.02$ & - & - & - & $1.97 \pm 0.01$ & $0.67 \pm 0.01$ \\
\hline$\alpha$-Cadinol & 1655 & 2208 & $1.28 \pm 0.05$ & - & - & - & - & $1.25 \pm 0.01$ \\
\hline Phenolic compounds & & & 43.05 & 2.17 & 3.36 & 6.26 & 10.33 & 11.75 \\
\hline Eugenol * & 1370 & 2175 & $7.48 \pm 0.01$ & $1.02 \pm 0.01$ & - & - & - & - \\
\hline Myristicin & 1520 & 2260 & $35.57 \pm 0.01$ & $1.15 \pm 0.01$ & $3.36 \pm 0.01$ & $6.26 \pm 0.01$ & $10.33 \pm 0.01$ & $11.75 \pm 0.01$ \\
\hline Hydrocarbons & & & 0.46 & 2.97 & 3.27 & 3.57 & 6.01 & 3.67 \\
\hline
\end{tabular}


Table 3. Cont.

\begin{tabular}{|c|c|c|c|c|c|c|c|c|}
\hline \multicolumn{9}{|c|}{ Month of Collection/ Yield in $\% \pm$ SD } \\
\hline Component & $\mathrm{RI}^{\mathbf{1}}$ & $\mathrm{RI}^{2}$ & December & January & February & March & April & May \\
\hline Heneicosane * & 2100 & 2100 & - & - & - & - & - & $0.32 \pm 0.01$ \\
\hline Docosane * & 2200 & 2200 & $0.46 \pm 0.01$ & $0.94 \pm 0.01$ & $3.27 \pm 0.01$ & $3.31 \pm 0.01$ & $4.89 \pm 0.01$ & $1.15 \pm 0.01$ \\
\hline Tricosane * & 2300 & 2300 & - & $0.35 \pm 0.03$ & - & - & $0.46 \pm 0.01$ & $0.94 \pm 0.07$ \\
\hline Tetracosane * & 2400 & 2400 & - & $0.67 \pm 0.03$ & - & - & $0.66 \pm 0.01$ & $1.26 \pm 0.01$ \\
\hline Pentacosane * & 2500 & 2500 & - & $0.46 \pm 0.01$ & - & - & - & - \\
\hline Hexacosane * & 2600 & 2600 & - & $0.55 \pm 0.02$ & - & - & - & - \\
\hline Heptacosane * & 2700 & 2700 & - & - & - & $0.26 \pm 0.01$ & - & - \\
\hline 1-Hexanol & 863 & 1350 & $0.97 \pm 0.07$ & $1.23 \pm 0.01$ & $1.22 \pm 0.01$ & $1.47 \pm 0.01$ & $2.51 \pm 0.01$ & $0.12 \pm 0.01$ \\
\hline n-Decanol & 1266 & 1714 & - & $18.66 \pm 0.01$ & $0.32 \pm 0.01$ & $0.27 \pm 0.01$ & $\begin{array}{c}-0.01 \\
-\end{array}$ & $\begin{array}{c}0.12+0.01 \\
-\end{array}$ \\
\hline n-Dodecanol & 1469 & 1960 & - & $\begin{array}{c}-0.001 \\
-\end{array}$ & $\begin{array}{c}0.02+0.01 \\
-\end{array}$ & $5.16 \pm 0.01$ & - & - \\
\hline Acids & & & 3.15 & 2.67 & 12.82 & 11.12 & 9.69 & 7.02 \\
\hline Hexadecanoic acid & 1959 & 2913 & $1.97 \pm 0.01$ & - & $0.25 \pm 0.04$ & - & $2.71 \pm 0.01$ & $4.67 \pm 0.01$ \\
\hline Oleic acid & 2139 & - & $1.18 \pm 0.05$ & $2.67 \pm 0.01$ & $12.57 \pm 0.01$ & $11.12 \pm 0.01$ & $6.98 \pm 0.01$ & $2.35 \pm 0.02$ \\
\hline Aldehydes & & & - & 3.98 & 4.67 & 3.76 & - & - \\
\hline n-Nonanal & 1100 & 1390 & - & - & $1.28 \pm 0.03$ & $3.76 \pm 0.01$ & - & - \\
\hline (E,Z)-2,6-Nonadienal & 1150 & 1582 & - & - & $3.39 \pm 0.01$ & - & - & - \\
\hline Ketones & & & 32.33 & 50.99 & 51.65 & 7.59 & 41.1 & 51.27 \\
\hline (E)- $\beta$-Damascenone & 1384 & 1819 & $19.12 \pm 0.01$ & $10.64 \pm 0.01$ & $8.78 \pm 0.01$ & $6.58 \pm 0.01$ & $16.37 \pm 0.01$ & $16.89 \pm 0.01$ \\
\hline$\alpha$-Ionone & 1427 & 1843 & $3.28 \pm 0.01$ & - & - & $0.66 \pm 0.01$ & $8.76 \pm 0.02$ & $9.05 \pm 0.01$ \\
\hline$\beta$-Ionone & 1487 & 1935 & $9.93 \pm 0.01$ & $40.35 \pm 0.01$ & $42.87 \pm 0.01$ & $0.35 \pm 0.01$ & $15.97 \pm 0.01$ & $25.33 \pm 0.01$ \\
\hline Esters & & & - & - & 12.41 & 9.91 & - & - \\
\hline endo-Fenchyl acetate & 1218 & 1465 & - & - & $2.75 \pm 0.02$ & - & - & - \\
\hline Linalyl acetate & 1252 & 1553 & - & - & $9.66 \pm 0.01$ & $9.91 \pm 0.01$ & - & - \\
\hline Total identification (\%) & & & 93.71 & 92.58 & 92.77 & 92.87 & 95.87 & 95.69 \\
\hline
\end{tabular}

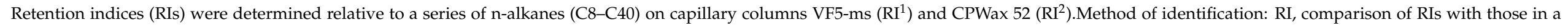

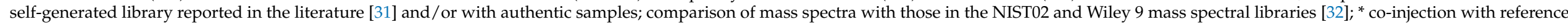
compounds; -, not identified; SD, standard deviation of triplicate analysis. 


\subsubsection{Composition of Essential Oil}

Table 2 shows the composition and percentage of identified FVCs in leaves of $\mathrm{O}$. europaea $\mathrm{cv}$. Oblica analyzed for six months. The total oil content was $0.1 \%$ for December to February, $0.04 \%$ in March, $0.2 \%$ in April and $0.08 \%$ in May (Table 1), based on the dry weight of the samples. These differences in percentage utilization can be explained by the differences in weathering and vegetation development of the olives. The winter months are the dormant period of the olives, and the total percentage of oil content is constant. Phenological growth of new olive leaves begins in March and lasts until November, but the time at which each growth stage is reached varies depending on the variety or year [32]. In April, a total oil content of $0.2 \%$ is formed due to the high metabolic activity in the leaves. The month of May is the time of budding and it is physiologically understandable that the metabolic products are directed from the leaves to the new vegetative shoots.

Differences were not only observed in the percentage of total oil, but also in the composition of the FVCs, as shown in Table 2. In the composition of identified volatile metabolites of olive leaves in December, the most abundant compounds are myristicin $(33.02 \%)$, caryophyllene oxide $(17.13 \%)$ and oleic acid $(8.11 \%)$. These components are most abundant in January with a similar percentage of identification as in December (myristicin $27.85 \%$, caryophyllene oxide $21.27 \%$ and oleic acid $6.74 \%$ ). In the composition of the EO isolated in February, linalyl acetate (11.28\%), endo-fenchyl acetate (12.75\%), $\alpha$-cubebene $(10.54 \%)$ are the main components. These esters and sesquiterpene hydrocarbon were identified only in February, they were not detected in the other five months. According to Dursun et al., (2017) $\alpha$-cubebene is a major compound collected in December of olive leaves from Hatay province (Turkey). In this study it was identified only in February with a value of $10.54 \%$ [39]. Linalool was identified in February with a high value of $9.35 \%$, while in December it was detected only with a value of less than one percent. The isolates from March are rich in docosane $(40.12 \%)$, allo-aromadendrene (20.94\%) and $\beta$-caryophyllene $(10.45 \%)$. These compounds were identified in all months with the highest yield in March. The compound (E)- $\beta$-damascenone was also identified in March with a high percentage of $10.45 \%$, having previously been identified in January with $0.52 \%$. In April, the value of (E)- $\beta$-damascenone fell to $5.02 \%$, and the dominant compounds were $\beta$-ionone $(20.48 \%)$, $\alpha$-ionone $(18.56 \%)$, and $\alpha$-humulene $(18.53 \%)$. The compound $\beta$-ionone is formed as a cleavage product of $\beta$-carotene and it has a significant ecological role in attracting insects or as a repellent, and a significant biomedical role: antibacterial, fungicidal, anticancer and other benefits to human health [40]. The compound $\alpha$-humulene (14.75\%) was significantly present in May, followed by (E)- $\beta$-damascenone (14.55\%).

Overall, the compounds $\beta$-caryophyllene (0.39-10.45\%), $\alpha$-humulene $(0.72-18.53 \%)$, allo-aromadendrene (1.44-20.94\%), docosane (3.46-40.12\%), hexadecanoic acid (0.75-9.93\%) and oleic acid (3.36-8.94\%) were identified in all the study periods (Table 2). The $\beta$ caryophyllene and ( $E$ )- $\beta$-damascenone were identified of March, April, August and November from Tunisian olive [41]. The (E)- $\beta$-damascenone was a one of major compound in Croatian cv. Oblica from period August, September and October [6] so it can be concluded that this compound is synthesized throughout the year.

\subsubsection{Composition of Hydrosol}

Free volatile compounds of olive leaves identified from the aqueous part of the extract in all study months are $\alpha$-pinene (1.36-7.45\%), $\beta$-ionone $(0.35-40.35 \%)$, myristicin $(1.15-35.57 \%)$, docosane $(0.46-4.89 \%)$, 1-hexanol (0.12-2.51\%), oleic acid (1.18-12.57\%) and (E)- $\beta$-damascenone (6.58-19.12\%) (Table 3). Docosane and oleic acid were also identified in all months of the oil phase (Table 2). Myristicin is the most abundant compound in December Hy phase and belongs to the group of apiols known for their synergistic effects. It is used as an antidepressant, anti-inflammatory, UV-B protectant, insecticide and antioxidant [42,43].

The following compounds were identified in the hydrosols in only one month of the study (with a percentage higher than $2 \%$ ), namely: bicyclogermacrene was identified in 
March with a high percentage of $39.54 \%$ as well as n-dodecanol identified with $5.16 \%$; n-decanal (3.98\%) and germacrene D (4.79\%) are compounds identified only in January; endo-fenchyl acetate $(2.75 \%)$ in February; $\alpha$-thujene (7.12\%) in April; $\alpha$-copaene (3.55\%) in May. The compound linalyl acetate was identified in February and March with a percentage slightly less than $10 \%$ for both months.

\subsection{Antioxidant Capacity}

Olive leaves are the sites of synthesis of primary and secondary (specialized) metabolites with phenolic compounds being the most investigated category of specialized metabolites in the terms of their composition in the olive leaves and their biological activity [44]. Papoti et al. investigated antioxidant capacity of the phenolic compounds from the Greek olive tree cultivars [45]. They found that methanol and ethanol extracts showed almost identical DPPH capacity. Ferreira et al. investigated antioxidant capacity of phenolic compounds from the olive leaves and they found that copper formulation sprayed on the olive leaves affect their phenolic composition and therefore DPPH capacity [46]. Highest antioxidant capacity showed leaves that were not sprayed with any copper formulations and their values were similar to those of the reference compounds. Kiritsakis et al. in their research of antioxidant capacity of phenolic extracts from Greek cultivars of olive leaves concluded that part of the capacity comes from other unidentified compounds [47]. These unidentified compounds could be terpenes and other volatile compounds which are the subject of this study.

In the Table 4 results for the antioxidant capacity of the free volatile compound extracts measured with two methods, ORAC and DPPH, were reported. In the ORAC method, $\mathrm{EO}$ and hydrosol from the February sample had the highest capacity $(73.12 \pm 5.24$ and $82.66 \pm 4.37 \mu \mathrm{mol} / \mathrm{g}$, respectively) with the hydrosol having slightly higher capacity than the EO. In the DPPH method, EO and hydrosol from the March sample showed the highest capacity $\left(\mathrm{IC}_{50} 23.58 \pm 0.18\right.$ and $4.16 \pm 0.28 \mathrm{mg} / \mathrm{mL}$, respectively) with hydrosol having approximately five times higher antioxidant capacity than the EO. This is in agreement with another study by Blasi et al. in which they studied seasonal variations in antioxidant capacity of phenolic compounds. They reported the highest antioxidant activity in March [48]. In general, hydrosols from all studied leaf stages of vegetation have higher antioxidant capacity than EOs (Figure 1). This is probably due to the higher content of volatile compounds isolated in hydrosols when compared to the amounts in the EOs (Table 1). Also, when comparing the identified compounds in the EOs and hydrosols it can be seen that hydrosols contain more identified compounds belonging to monoterpene hydrocarbons. Ruberto et al. found that compounds from this category showed significant antioxidant capacity [49]. The reason for the higher antioxidant capacity of the olive leaves collected in February could be due to higher percentage of linalool when compared to other months (9.35 $\pm 0.01 \%)$. Baschieri et al. studied antioxidant activity of some common non-phenolic compounds found in EOs and their study showed that linalool can contribute to the antioxidant capacity of natural essential oils [50]. The essential oil from March have higher percentage of $\beta$-caryophyllene that is known for its antioxidant that appears to be similar to the activity of the ascorbic acid [51]. Hydrosols from March have high percentage of bicyclogermacrene $(39.54 \pm 0.01 \%)$ when comparing to other months and this could potentially be the reason for the highest activity when measured by DPPH method. In a study by da Silva et al., where they compared antioxidant activity of the EO from Endlicheria arenosa leaves and twigs, leaves had high content of bicyclogermacrene and this EO shoed higher activity than the EO from twigs [52]. Hydrosols from February and March have high relative amount of $\beta$-Ionone ( $40.35 \pm 0.01 \%, 42.87 \pm 0.01 \%$, respectively) which could also be the reason for higher antioxidant capacity in these months. 
Table 4. Antioxidant capacity of the EOs and hydrosols of Olea europaea L. cv. Oblica over the period of six months.

\begin{tabular}{|c|c|c|c|c|c|c|}
\hline \multicolumn{7}{|c|}{ Essential Oils } \\
\hline Antioxidant Assay & December & January & February & March & April & May \\
\hline ORAC (Trolox eq) & $9.28 \pm 1.19^{b}$ & $11.44 \pm 0.08^{\mathrm{b}}$ & $73.12 \pm 5.24^{\mathrm{a}}$ & $9.66 \pm 0.24^{b}$ & $16.93 \pm 0.43^{b}$ & $4.43 \pm 0.16^{b}$ \\
\hline DPPH (\% inhibition) & $4.64 \pm 0.03^{b}$ & $4.48 \pm 0.52^{b}$ & $6.72 \pm 0.14^{\mathrm{b}}$ & $21.71 \pm 0.25^{\mathrm{a}}$ & $10.73 \pm 0.57^{\mathrm{ab}}$ & $4.95 \pm 0.16^{b}$ \\
\hline DPPH (IC 50) & $127.71 \pm 3.38^{\mathrm{d}}$ & $130.71 \pm 18.34^{\mathrm{d}}$ & $78.25 \pm 0.90^{\mathrm{b}}$ & $23.58 \pm 0.18^{\mathrm{a}}$ & $86.15 \pm 3.05^{b}$ & $105.18 \pm 5.71^{c}$ \\
\hline \multicolumn{7}{|c|}{ Hydrosols } \\
\hline Antioxidant Assay & December & January & February & March & April & May \\
\hline ORAC (Trolox eq) & $23.62 \pm 4.40^{c}$ & $36.83 \pm 0.66^{b}$ & $82.66 \pm 4.37^{\mathrm{a}}$ & $29.28 \pm 0.76^{b c}$ & $20.31 \pm 1.30^{c}$ & $12.39 \pm 1.71^{\mathrm{d}}$ \\
\hline DPPH (\% inhibition) & $69.99 \pm 2.62^{c}$ & $92.04 \pm 3.83^{\mathrm{a}}$ & $50.19 \pm 1.33^{d}$ & $98.06 \pm 6.52^{a}$ & $29.56 \pm 1.06^{\mathrm{e}}$ & $78.20 \pm 4.16^{b}$ \\
\hline DPPH (IC 50) & $9.01 \pm 0.33^{\mathrm{a}}$ & $5.41 \pm 0.23^{\mathrm{a}}$ & $9.96 \pm 0.26^{\mathrm{ab}}$ & $4.16 \pm 0.28^{a}$ & $16.91 \pm 0.61^{\mathrm{b}}$ & $6.39 \pm 0.34^{\mathrm{a}}$ \\
\hline
\end{tabular}

ORAC, oxygen radical absorbance capacity, results for EOs expressed as $\mu \mathrm{mol}$ of Trolox equivalents (TE) per g of EO (10 mg/mL) and for hydrosols as $\mu \mathrm{mol}$ of Trolox equivalents (TE) per $\mathrm{g}$ of the total (undiluted) tested hydrosol sample (10 $\mathrm{mg}$ volatiles $/ \mathrm{mL}$ of hydrosol); $\mathrm{DPPH}$, percentage (\%) of inhibition was calculated for the concentrations of EOs and hydrosols of $10 \mathrm{mg} / \mathrm{mL}$; IC50 expressed in mg/mL; $\mathrm{SD}$ = standard deviation of triplicate analysis; significant differences were determined using 2-way ANOVA followed by Šídák's multiple comparisons test. $\mathrm{a}, \mathrm{b}, \mathrm{c}, \mathrm{d}, \mathrm{e}$ Mean values in the same row with different superscript letters indicate a statistically significant difference between data from six months $(p<0.05)$.

(a)

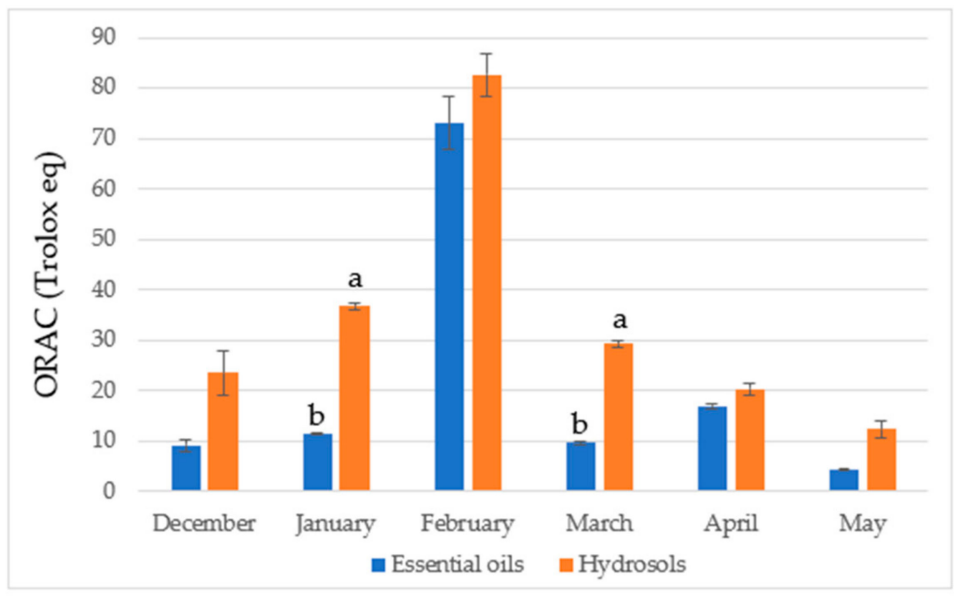

(b)

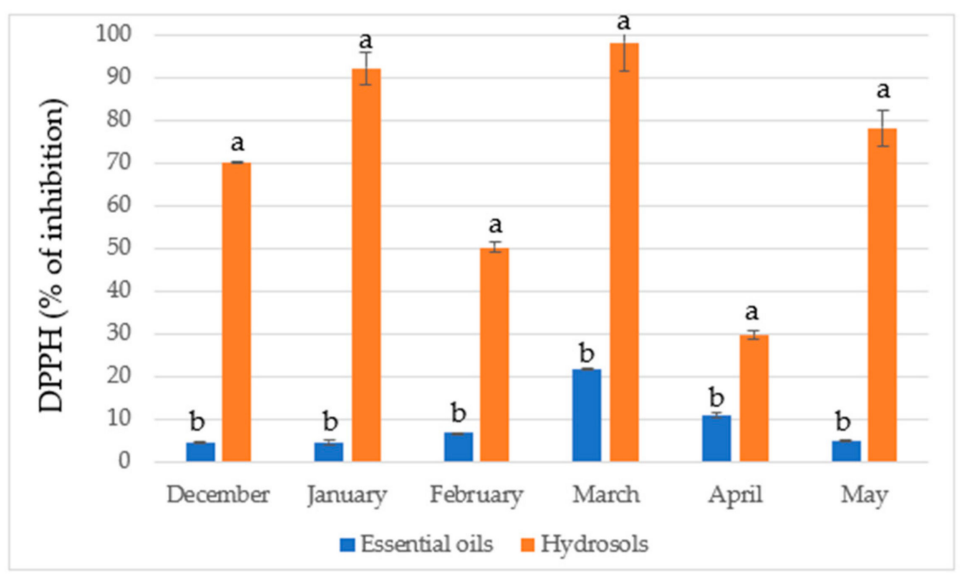

Figure 1. Antioxidant capacity determined by (a) ORAC assay ( $\mu \mathrm{mol} \mathrm{TE} / \mathrm{g}$, mean values) and (b) DPPH assay (percentage of inhibition, mean values) in olive leaves harvested in different periods from Oblica cultivar. Error bars indicate SD of the means $(n=3)$; significant differences between EOs and hydrosols were determined using multiple t-test. ${ }^{a, b}$ Mean values with different superscript letters indicate a statistically significant difference between EOs and hydrosols for each month $(p<0.05)$. 
Viuda-Martos et al. tested the antioxidant activity of EOs from five spice plants that are commonly used in the Mediterranean and comparing their results with current study it can be noticed that all samples of hydrosols have higher activity than rosemary EO $(17 \mathrm{mg} / \mathrm{mL})$ and the hydrosol from March has similar activity to the activity of sage EO $(4.20 \mathrm{mg} / \mathrm{mL})$ [53]. Many studies have confirmed that olive leaves are a potential source of biologically active by-products of olive oil production generated during pruning [44]. The results show that the antioxidant capacity of volatiles was highest from in February and March. The fact that olive leaf pruning is very important at this stage of vegetation suggests the potential use of pruned leaves as an antioxidant source that can be used in pharmacy and food protection. Future research on these extracts may address their antimicrobial, antiproliferative and antiphytoviral potential.

\section{Conclusions}

The results of this study show that oleic acid and docosane are components identified in the hydrophilic and lipophilic phases, i.e., essential oil and hydrosol, extracted from the leaves of Olea europaea cv. Oblica in all study periods. Other significant FVCs greater than $10 \%$ identified in at least one month of research are: $\beta$-cubebene, $\beta$-caryophyllene, $\alpha$-humulene, allo-aromadendrene, bicyclogermacrene, caryophyllene oxide, myristicin, $(E)$ $\beta$-damascenone, $\alpha$-ionone, $\beta$-ionone, endo-fenchyl acetate and linalyl acetate. Despite the numerous biological effects of olive leaf polyphenols, this study showed that leaf essential oils also have a significant antioxidant capacity, reaching their maximum in February and March. For the first time, the hydrosols of olive leaves were phytochemically analyzed and the data showed that these harmless water extracts could also be a readily available source of biologically active substances with pronounced antioxidant activity. Volatile compounds showed highest antioxidant capacity in February and March, when olive trees begin new growing season and become more metabolically active. Overall, higher levels of volatile compounds were found in hydrosols, and they also exhibited higher antioxidant capacity than the essential oils in both methods used. This study showed that the previously described phenolic compounds are not the only specialized metabolites involved in the antioxidant capacity of olive leaves. Free volatile compounds contribute to the total antioxidant capacity of olive leaves.

Author Contributions: Conceptualization, R.J.G., M.N. and V.D.; methodology, M.N. and V.D.; validation, R.J.G., M.N. and V.D.; formal analysis, T.M., M.N., N.V., I.L., V.D. and E.V.; investigation, T.M., M.N. and V.D.; data curation, R.J.G. and V.D.; writing-original draft preparation, R.J.G., M.N. and V.D.; writing—review and editing, R.J.G., M.N. and V.D.; visualization, R.J.G., M.N. and V.D.; supervision, V.D.; funding acquisition, V.D. All authors have read and agreed to the published version of the manuscript.

Funding: This research received no external funding.

Institutional Review Board Statement: Not applicable.

Informed Consent Statement: Not applicable.

Data Availability Statement: The data is contained within the article.

Acknowledgments: Authors thank reviewers for their helpful comments and suggestions.

Conflicts of Interest: The authors declare no conflict of interest.

\section{References}

1. Parvaiz, M.; Hussain, K.; Shoaib, M.; William, G.; Tufail, M.; Hussain, Z.; Gohar, D.; Imtiaz, S. A review: Therapeutic significance of olive Olea europaea L. (oleaceae family). Glob. J. Pharmacol. 2013, 7, 333-336. [CrossRef]

2. Visioli, F.; Poli, A.; Galli, C. Antioxidant and other biological activities of phenols from olives and olive oil. Med. Res. Rev. 2002, 22, 65-75. [CrossRef] [PubMed]

3. Connor, D.J. Adaptation of olive (Olea europaea L.) to water-limited environments. Aust. J. Agric. Res. 2005, 56, 1181-1189. [CrossRef] 
4. Guerrero Maldonado, N.; López, M.J.; Caudullo, G.; de Rigo, D. Olea europaea in Europe: Distribution, habitat, usage and threats. Eur. Atlas For. Tree Species 2016, 111, e01534b.

5. Strikic, F.; Mavsar, D.B.; Perica, S.; Cmelik, Z.; Satovic, Z.; Javornik, B. The main croatian olive cultivar, "oblica", shows high morphological but low molecular diversity. J. Hortic. Sci. Biotechnol. 2009, 84, 345-349. [CrossRef]

6. Popović, M.; Jukić Špika, M.; Veršić Bratinčević, M.; Ninčević, T.; Matešković, A.; Mandušić, M.; Rošin, J.; Nazlić, M.; Dunkić, V.; Vitanović, E. Essential Oil Volatile Fingerprint Differentiates Croatian cv. Oblica from Other Olea europaea L. Cultivars. Molecules 2021, 26, 3533. [CrossRef]

7. Vogel, P.; Machado, I.K.; Garavaglia, J.; Zani, V.T.; de Souza, D.; Dal Bosco, S.M. Beneficios polifenoles hoja de olivo (Olea europaea L.) para la salud humana. Nutr. Hosp. 2015, 31, 1427-1433. [CrossRef]

8. Covas, M.-I.; De la Torre, R.; Fitó, M. Scientific evidence of the benefits of virgin olive oil for human health. Med. Balear 2014, 29, 39-46. [CrossRef]

9. Pereira, A.P.; Ferreira, I.C.F.R.; Marcelino, F.; Valentão, P.; Andrade, P.B.; Seabra, R.; Estevinho, L.; Bento, A.; Pereira, J.A. Phenolic compounds and antimicrobial activity of olive (Olea europaea L. Cv. Cobrançosa) leaves. Molecules 2007, 12, 1153-1162. [CrossRef] [PubMed]

10. Şahin, S.; Bilgin, M. Olive tree (Olea europaea L.) leaf as a waste by-product of table olive and olive oil industry: A review. J. Sci. Food Agric. 2018, 98, 1271-1279. [CrossRef] [PubMed]

11. Hashmi, M.A.; Khan, A.; Hanif, M.; Farooq, U.; Perveen, S. Traditional uses, phytochemistry, and pharmacology of olea europaea (olive). Evid. Based Complement. Altern. Med.Vol. 2015, 2015, 541591. [CrossRef]

12. Vilaplana-Pérez, C.; Auñón, D.; García-Flores, L.A.; Gil-Izquierdo, A. Hydroxytyrosol and Potential Uses in Cardiovascular Diseases, Cancer, and AIDS. Front. Nutr. 2014, 1, 18. [CrossRef]

13. Japón-Luján, R.; Ruiz-Jiménez, J.; De Castro, M.D.L. Discrimination and classification of olive tree varieties and cultivation zones by biophenol contents. J. Agric. Food Chem. 2006, 54, 9706-9712. [CrossRef] [PubMed]

14. Boss, A.; Bishop, K.S.; Marlow, G.; Barnett, M.P.G.; Ferguson, L.R. Evidence to support the anti-cancer effect of olive leaf extract and future directions. Nutrients 2016, 8, 513. [CrossRef] [PubMed]

15. Suárez Montenegro, Z.J.; Álvarez-Rivera, G.; Mendiola, J.A.; Ibáñez, E.; Cifuentes, A. Extraction and mass spectrometric characterization of terpenes recovered from olive leaves using a new adsorbent-assisted supercritical $\mathrm{CO}_{2}$ process. Foods 2021, 10, 1301. [CrossRef]

16. Tiwari, R.; Rana, C.S. Plant secondary metabolites: A review. Int. J. Eng. Res. Gen. Sci. 2015, 3, 661-670.

17. Barbulova, A.; Colucci, G.; Apone, F. New trends in cosmetics: By-products of plant origin and their potential use as cosmetic active ingredients. Cosmetics 2015, 2, 82-92. [CrossRef]

18. Omar, S.H. Oleuropein in olive and its pharmacological effects. Sci. Pharm. 2010, 78, 133-154. [CrossRef] [PubMed]

19. Al-Quraishy, S.; Othman, M.S.; Dkhil, M.A.; Abdel Moneim, A.E. Olive (Olea europaea) leaf methanolic extract prevents $\mathrm{HCl}$ /ethanol-induced gastritis in rats by attenuating inflammation and augmenting antioxidant enzyme activities. Biomed. Pharmacotherapy 2017, 91, 338-349. [CrossRef]

20. Crozier, A.; Clifford., M.N.; Ashihara, H. Plant Secondary Metabolites: Occurrence, Structure and Role in the Human Diet; Crozier, A., Mike, N., Hiroshi, A., Eds.; Blackwell Publishing: Oxford, UK, 2006; p. 384. ISBN 978-1-405-12509-3.

21. Hassen, I.; Casabianca, H.; Hosni, K. Biological activities of the natural antioxidant oleuropein: Exceeding the expectation-A mini-review. J. Funct. Foods 2015, 18, 926-940. [CrossRef]

22. Musa, A.; Shady, N.H.; Ahmed, S.R.; Alnusaire, T.S.; Sayed, A.M.; Alowaiesh, B.F.; Sabouni, I.; Al-sanea, M.M.; Mostafa, E.M.; Youssif, K.A.; et al. Antiulcer potential of olea europea l. Cv. arbequina leaf extract supported by metabolic profiling and molecular docking. Antioxidants 2021, 10, 644. [CrossRef] [PubMed]

23. Sanmartin, C.; Taglieri, I.; Macaluso, M.; Sgherri, C.; Ascrizzi, R.; Flamini, G.; Venturi, F.; Quartacci, M.F.; Luro, F.; Curk, F.; et al. Cold-pressing olive oil in the presence of cryomacerated leaves of olea or citrus: Nutraceutical and sensorial features. Molecules 2019, 24, 2625. [CrossRef] [PubMed]

24. Guinda, Á.; Castellano, J.M.; Santos-Lozano, J.M.; Delgado-Hervás, T.; Gutiérrez-Adánez, P.; Rada, M. Determination of major bioactive compounds from olive leaf. LWT-Food Sci. Technol. 2015, 64, 431-438. [CrossRef]

25. Koprivnjak, O.; Majetić, V.; Bubola, K.B.; Kosić, U. Variability of phenolic and volatile compounds in virgin olive oil from leccino and istarska bjelica cultivars in relation to their fruit mixtures. Food Technol. Biotechnol. 2012, 50, 216-221.

26. Haloui, E.; Marzouk, Z.; Marzouk, B.; Bouftira, I.; Bouraoui, A.; Fenina, N. Pharmacological activities and chemical composition of the Olea europaea L. leaf essential oils from Tunisia. J. Food Agric. Environ. 2010, 8, 204-208.

27. Vural, N.; Akay, M.A. Chemical compounds, antioxidant properties and antimicrobial activity of olive leaves derived volatile oil in West Anatolia. J. Turk. Chem. Soc. Sect. A Chem. 2021, 8, 511-518. [CrossRef]

28. Cavalheiro, C.V.; Rosso, V.D.; Paulus, E.; Cichoski, A.J.; Wagner, R.; de Menezes, C.R.; Barin, J.S. Chemical composition of olive leaves (Olea europaea L.) from the region of caçapava do Sul, Rs, Brazil. Ciênc. Rural 2014, 44, 1874-1879. [CrossRef]

29. Campeol, E.; Flamini, G.; Cioni, P.L.; Morelli, I.; Cremonini, R.; Ceccarini, L. Volatile fractions from three cultivars of Olea europaea L. Collected in two different seasons. J. Agric. Food Chem. 2003, 51, 1994-1999. [CrossRef]

30. Makowska-Wąs, J.; Galanty, A.; Gdula-Argasińska, J.; Tyszka-Czochara, M.; Szewczyk, A.; Nunes, R.; Carvalho, I.S.; Michalik, M.; Paśko, P. Identification of Predominant Phytochemical Compounds and Cytotoxic Activity of Wild Olive Leaves (Olea europaea L. ssp. sylvestris) Harvested in South Portugal. Chem. Biodivers. 2017, 14, 1-10. [CrossRef] 
31. Adams, R.P. Identification of Essential Oil Components by Gas Chromatography/Mass Spectrometry; Allured Publishing: Carol Stream, IL, USA, 2017; ISBN 978-1-932633-21-4.

32. NIST Chemistry WebBook. Available online: https:/ / webbook.nist.gov/ (accessed on 12 March 2021).

33. Nazlić, M.; Kremer, D.; Jurišić-Grubešić, R.; Soldo, B.; Vuko, E.; Stabentheiner, E.; Ballian, D.; Bogunić, F.; Dunkić, V. Endemic Veronica saturejoides Vis. ssp. saturejoides-Chemical Composition and Antioxidant Activity of Free Volatile Compounds. Plants 2020, 9, 1646. [CrossRef] [PubMed]

34. Fredotović, Ž.; Šprung, M.; Soldo, B.; Ljubenkov, I.; Budić-Leto, I.; Bilušić, T.; Cikeš-Čulić, V.; Puizina, J. Chemical composition and biological activity of allium cepa L. and Allium $\times$ cornutum (Clementi ex Visiani 1842) methanolic extracts. Molecules 2017, 22, 448. [CrossRef] [PubMed]

35. Mensor, L.L.; Menezes, F.S.; Leitão, G.G.; Reis, A.S.; Santos, T.C.; Coube, C.S.; Leitão, S.G. Screening of Brazilian plant extracts for antioxidant activity by the use of DPPH free radical method. Phyther. Res. 2001, 15, 127-130. [CrossRef]

36. Payet, B.; Sing, A.S.C.; Smadja, J. Assessment of antioxidant activity of cane brown sugars by ABTS and DPPH radical scavenging assays: Determination of their polyphenolic and volatile constituents. J. Agric. Food Chem. 2005, 53, 10074-10079. [CrossRef] [PubMed]

37. Koudounas, K.; Manioudaki, M.E.; Kourti, A.; Banilas, G.; Hatzopoulos, P. Transcriptional profiling unravels potential metabolic activities of the olive leaf non-glandular trichome. Front. Plant Sci. 2015, 6, 633. [CrossRef] [PubMed]

38. Mylonaki, S.; Kiassos, E.; Makris, D.P.; Kefalas, P. Optimisation of the extraction of olive (Olea europaea) leaf phenolics using water/ethanol-based solvent systems and response surface methodology. Anal. Bioanal. Chem. 2008, 392, 977-985. [CrossRef]

39. Dursun, A.; Güler, Z.; Özkan, D.; Bozdoğan Konuşkan, D. Identification of Volatile Compounds (VCs) in the Leaves Collected from 'Gemlik', 'Halhalı' and 'Sar1 Hasebi' Olive Tree Varieties. Int. J. Second. Metab. 2017, 4, 195-204. [CrossRef]

40. Paparella, A.; Shaltiel-harpaza, L.; Ibdah, M. $\beta$-Ionone: Its Occurrence and Biological Function and Metabolic Engineering. Plants 2021, 10, 754. [CrossRef] [PubMed]

41. Abdeljelil, Z.B.; Tekaya, M.; Mechri, B.; Flamini, G.; Hammami, M. Changes in volatiles of olive tree Olea europaea according to season and foliar fertilization. Int. J. Agric. Biol. 2017, 19, 1633-1639. [CrossRef]

42. Ansory, H.M.; Sari, E.N.; Nilawati, A.; Handayani, S.; Aznam, N. Sunscreen and Antioxidant Potential of Myristicin in Nutmeg Essential Oils (Myristica fragrans). In Proceedings of the 2nd Bakti Tunas Husada-Health Science International Conference (BTH-HSIC), Paris, France, 5-6 October 2019; pp. 138-142.

43. Srivastava, S.; Gupta, M.M.; Prajapati, V.; Tripathi, A.K.; Kumar, S. Insecticidal activity of myristicin from piper mullesua. Pharm. Biol. 2001, 39, 226-229. [CrossRef]

44. Abaza, L.; Taamalli, A.; Nsir, H.; Zarrouk, M. Olive tree (Olea europeae L.) leaves: Importance and advances in the analysis of phenolic compounds. Antioxidants 2015, 4, 682-698. [CrossRef] [PubMed]

45. Papoti, V.T.; Papageorgiou, M.; Dervisi, K.; Alexopoulos, E.; Apostolidis, K.; Petridis, D. Screening olive leaves from unexploited traditional Greek cultivars for their phenolic antioxidant dynamic. Foods 2018, 7, 197. [CrossRef] [PubMed]

46. Ferreira, I.C.F.R.; Barros, L.; Soares, M.E.; Bastos, M.L.; Pereira, J.A. Antioxidant activity and phenolic contents of Olea europaea L. leaves sprayed with different copper formulations. Food Chem. 2007, 103, 188-195. [CrossRef]

47. Kiritsakis, K.; Kontominas, M.G.; Kontogiorgis, C.; Hadjipavlou-Litina, D.; Moustakas, A.; Kiritsakis, A. Composition and antioxidant activity of olive leaf extracts from Greek olive cultivars. J. Am. Oil Chem. Soc. 2010, 87, 369-376. [CrossRef]

48. Blasi, F.; Urbani, E.; Simonetti, M.S.; Chiesi, C.; Cossignani, L. Seasonal variations in antioxidant compounds of Olea europaea leaves collected from different Italian cultivars. J. Appl. Bot. Food Qual. 2016, 89, 202-207. [CrossRef]

49. Ruberto, G.; Baratta, M.T. Antioxidant activity of selected essential oil components in two lipid model systems. Food Chem. 2000, 69, 167-174. [CrossRef]

50. Baschieri, A.; Ajvazi, M.D.; Tonfack, J.L.F.; Valgimigli, L.; Amorati, R. Explaining the antioxidant activity of some common non-phenolic components of essential oils. Food Chem. 2017, 232, 656-663. [CrossRef]

51. Dahham, S.S.; Tabana, Y.M.; Iqbal, M.A.; Ahamed, M.B.K.; Ezzat, M.O.; Majid, A.S.; Majid, A.M. The anticancer, antioxidant and antimicrobial properties of the sesquiterpene $\beta$-caryophyllene from the essential oil of Aquilaria crassna. Molecules 2015, 20, 11808-11829. [CrossRef] [PubMed]

52. da Silva, J.K.R.; da Trindade, R.C.S.; Maia, J.G.S.; Setzer, W.N. Chemical Composition, Antioxidant, and Antimicrobial Activities of Essential Oils of Endlicheria arenosa (Lauraceae) from the Amazon. Nat. Prod. Commun. 2016, 11, 695-698. [CrossRef]

53. Viuda-Martos, M.; Ruiz Navajas, Y.; Sanchez Zapata, E.; Fernandez-Lopez, J.; Perez-Alvarez, J.A. Antioxidant activity of essential oils of five spice plants widely used in a Mediterranean diet. Flavour Fragr. J. 2010, 25, 13-19. [CrossRef] 